\title{
New evidence for upper Permian crustal growth below Eifel, Germany, from mafic granulite xenoliths
}

\author{
Cliff S. J. Shaw \\ Department of Earth Sciences, University of New Brunswick, 2 Bailey Drive, \\ Fredericton, E3B 5A3, New Brunswick, Canada \\ Correspondence: Cliff S. J. Shaw (cshaw@unb.ca)
}

Received: 2 October 2020 - Revised: 24 February 2021 - Accepted: 14 March 2021 - Published: 29 April 2021

\begin{abstract}
Granulite xenoliths from the Quaternary West Eifel Volcanic Field in Germany record evidence of magmatism in the lower crust at the end of the Permian. The xenoliths sampled two distinct bodies: an older intrusion (ca. $264 \mathrm{Myr}$ old) that contains clinopyroxene with flat, chondrite-normalised rare earth element (REE) profiles and a younger (ca. $253 \mathrm{Myr}$ old) intrusion that crystallised middle-REE-rich clinopyroxene. The younger body is also distinguished based on the negative $\mathrm{Sr}, \mathrm{Zr}$ and $\mathrm{Ti}$ anomalies in primitive mantle-normalised multielement plots. REE-in-plagioclase-clinopyroxene thermometry records the magmatic temperature of the xenoliths $\left(1100-1300^{\circ} \mathrm{C}\right)$, whereas Mg-in-plagioclase and Zr-in-titanite thermometry preserve an equilibration temperature of ca. $800^{\circ} \mathrm{C}$. These temperatures, together with a model of the mineral assemblages predicted from the composition of one of the xenoliths, define the pressure of crystallisation as $\sim 1 \mathrm{GPa}$. The xenoliths also preserve a long history of reheating events whose age ranges from 220 to $6 \mathrm{Myr}$. The last of these events presumably led to breakdown of garnet; formation of symplectites of orthopyroxene, plagioclase and hercynite; and redistribution of heavy rare earth elements into clinopyroxene. The data from the West Eifel granulite xenoliths, when combined with the existing data from granulites sampled in the East Eifel, indicate that the lower crust has a long a complex history stretching from at least $1.6 \mathrm{Ga}$ with intrusive events at ca. 410 and $260 \mathrm{Ma}$ and reheating from the Triassic to late Miocene.
\end{abstract}

\section{Introduction}

Crustal xenoliths in volcanic rocks carry valuable information about deep subsurface geology and petrology that cannot be accessed in any other way. The textures, mineral assemblages and compositions of the xenoliths provide information on the age of the sampled crust, the pressure and temperature conditions of formation/equilibration. Knowledge of these permits correlation with regional- and continent-scale tectonic events. In particular, xenoliths of granulite facies metamorphic rocks carry information on the petrology and textural evolution of the lower crust (Rudnick and Goldstein, 1990) and may be important in understanding interactions between mantle-derived magmas and the deep lithosphere (Ernst and Liou, 2008).

The nature of the crust and mantle in the Eifel volcanic fields of Germany has been of interest for more than 4 decades because of the young age of volcanism (Schnepp and Hradetzky, 1994; Nowell et al., 2006; Shaw et al., 2010; Mertz et al., 2015) and the occurrence of P- and S-wave anomalies in the sub-Eifel mantle (Ritter et al., 2001; Keyser et al., 2002). Mantle xenoliths from the West Eifel field have attracted attention because they record multiple metasomatic events that have advanced our understanding of the evolution of the lithospheric mantle and the asthenospheric magmas that have interacted with it (Lloyd and Bailey, 1975; WittEickschen et al., 1998, 2003; Shaw et al., 2005; Mertz et al., 2015; Shaw et al., 2018). Although the lower crust is an important part of the deep lithosphere, its age and evolution in the Eifel region are poorly understood. Up to now, lower-crustal xenoliths have been described from only one location in the East Eifel (Illies et al., 1979; Okrusch et al., 1979; Stosch et al., 1986; Stosch, 1987; Loock et al., 1990; Mengel et al., 1991; Stosch et al., 1992). The East Eifel samples are garnet-bearing mafic granulites and amphibo- 


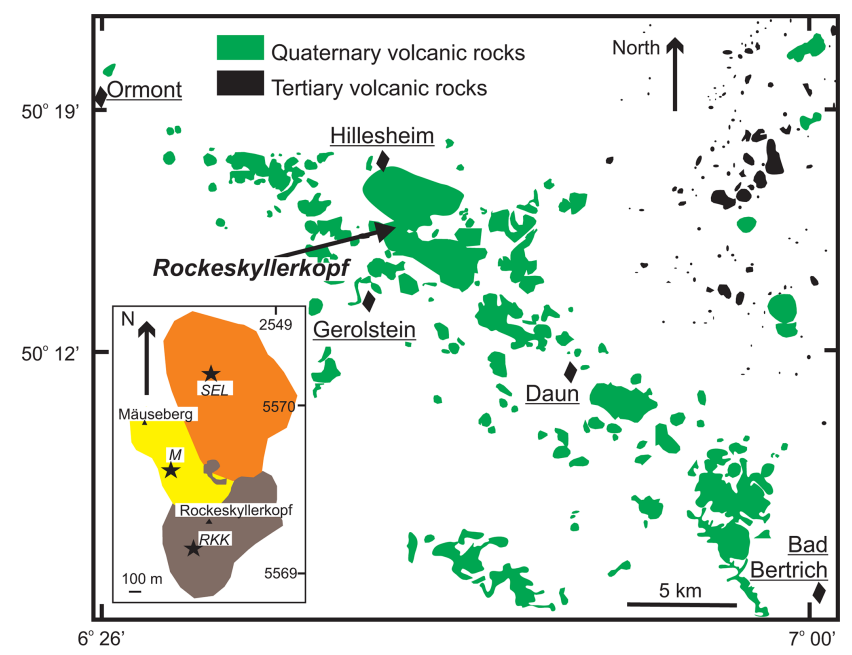

Figure 1. Distribution of Tertiary and Quaternary volcanic rocks in the West Eifel Volcanic Field. Towns are indicated by diamonds. The distribution of the three volcanic centres in the Rockeskyllerkopf Volcanic Complex (RVC) is shown in the inset. These are, from oldest to youngest, the SEL (South East Lammersdorf), M (Mäuseberg) and RKK (Rockeskyllerkopf) centres. Coordinates in the inset map refer to Rheinland Pfalz Topographische Karte Nr 5705 (Gauß-Krüger coordinate system). Regional geology modified from Büchel (1991); geology of the RVC modified from Shaw et al. (2010).

lites that comprise plagioclase, clinopyroxene, garnet, hornblende, orthopyroxene, scapolite, biotite, quartz and titanite.

Seismic studies in the Rhine graben region, of which the Eifel volcanic fields are a part, indicate a minimum depth to the Moho of ca. $25 \mathrm{~km}$ (Prodehl, 1981; Prodehl et al., 1992), which suggests a minimum pressure of ca. $0.75 \mathrm{GPa}$ at the Moho. Wörner et al. (1982) used data from seismic surveys, xenoliths and surface geology studies to develop a model of the crust in the East Eifel: this model has $2-5 \mathrm{~km}$ of Devonian sedimentary rocks overlying $15-18 \mathrm{~km}$ of low-grade metamorphic rocks and a $5 \mathrm{~km}$ thick high-grade granulitic lower crust. Seiberlich et al. (2013) showed that the lithosphereasthenosphere boundary is at $41 \pm 5 \mathrm{~km}$ below the Eifel and that the Moho is at $27-30 \mathrm{~km}$ depth.

This study examines the petrology and age of a new suite of quartz- and garnet-bearing mafic granulites that occur within the well-studied Rockeskyllerkopf Volcanic Complex in the West Eifel Volcanic Field (Shaw and Eyzaguirre, 2000; Shaw, 2009a; Shaw et al., 2010; Shaw and Woodland, 2012; Shaw et al., 2018). The occurrence of accessory titanite in these xenoliths affords the opportunity to obtain robust geochronological information that will help to refine our understanding of the evolution of the crust below the Eifel volcanic fields.

\section{Regional and sample site geology}

The West Eifel Volcanic Field (Fig. 1) was erupted onto Devonian and Triassic basement. Volcanism began $\sim$ $940 \mathrm{kyr} \mathrm{BP}$, and the last known eruption was $\sim 11 \mathrm{kyr} \mathrm{BP}$ (Hajdas et al., 1995; Zolitschka et al., 1995; Nowell et al., 2006). The field trends NW-SE and comprises around 240 volcanic centres, including maars, tuff rings, scoria cones and lava flows, with a total erupted volume of ca. $1.7 \mathrm{~km}^{3}$ (Büchel and Mertes, 1982; Mertes, 1983; Mertes and Schmincke, 1985). The granulite xenoliths for this study were collected from the Rockeskyllerkopf volcanic centre (Fig. 1, inset). This complex comprises three distinct eruptive centres that range in age from $474 \pm 39$ to $360 \pm 60 \mathrm{kyr}$ with evidence for at least one long break in activity in the form of a $1 \mathrm{~m}$ thick palaeosol (Mertes and Schmincke, 1983; Shaw et al., 2010). The granulite xenoliths were collected from the same horizons in the South East Lammersdorf (SEL) centre that host the peridotite and clinopyroxenite xenoliths and clinopyroxene and phlogopite megacrysts described by Shaw and Eyzaguirre (2000) and Shaw et al. (2005, 2018). Granulite xenoliths are extremely rare in these deposits. There are only 5 samples from a high-pressure xenolith suite of more than 700 samples.

\section{Analytical methods}

Major element compositions of clinopyroxene and plagioclase were determined by JEOL 733 electron probe using an accelerating voltage of $15 \mathrm{kV}$ and a beam current of $20 \mathrm{nA}$. Natural and synthetic clinopyroxene, hornblende, pyrope, albite and anorthite were used for standardisation. Counting times of $40 \mathrm{~s}$ were used on peak positions, and background positions were counted for $20 \mathrm{~s}$ each on either side of the peak. The resulting data were reduced using a ZAF correction.

Trace element compositions and $\mathrm{U}-\mathrm{Pb}$ in titanite were measured using a Resonetics S-155-LR excimer laser and an Agilent 7700x quadrupole inductively coupled plasma mass spectrometer, both located at the University of New Brunswick. Ablations were done with a carrier gas of $\mathrm{He}$ (300 $\left.\mathrm{mL} \mathrm{min}^{-1}\right)$ and $\mathrm{Ar}\left(930 \mathrm{~mL} \mathrm{~min}^{-1}\right)$; for U-Pb analyses sensitivity was increased using a downstream injection of $2 \mathrm{~mL} \mathrm{~min}^{-1} \mathrm{~N}_{2}$. Titanite was analysed with a laser energy of $4 \mathrm{~J} \mathrm{~cm}^{-2}$, a repetition rate of $5 \mathrm{~Hz}$ and a $33 \mu \mathrm{m}$ crater diameter. BLR-1 (1047.1 $\pm 0.4 \mathrm{Ma})$ and MKED (1521.02 \pm $0.055 \mathrm{Ma})$ were used as primary and secondary standards respectively (Aleinikoff et al., 2007; Spandler et al., 2016). $\mathrm{Zr}$ concentrations were measured using NIST 610 as a standard and the measured $\mathrm{Ca}$ content as an internal standard. Common lead corrections were applied using the net ${ }^{204} \mathrm{~Pb}$ signal, and the age estimated based on measurements of ${ }^{206} \mathrm{~Pb} /{ }^{238} \mathrm{U}$ and the common lead ratio evolution curves presented by Kramers and Tolstikhin (1997). Common lead cor- 
rections were applied for ${ }^{204} \mathrm{~Pb}>50 \mathrm{cps}$ and $1 \sigma$ internal error of $<25 \%$. Data were processed with Iolite 3.7 (Paton et al., 2011) and the VizualAge data reduction, UcomPbine (Chew et al., 2014). A complete listing of analytical and correction data are given in Supplement S1.

Trace elements in clinopyroxene and plagioclase were analysed using a $60 \mu \mathrm{m}$ spot and $0.15 \mathrm{~mJ}$ laser energy at $10 \mathrm{~Hz}$ with a fluence of $2.1 \mathrm{~J} \mathrm{~cm}^{-2}$. For elements with multiple naturally occurring isotopes the following were measured: ${ }^{47} \mathrm{Ti},{ }^{51} \mathrm{~V},{ }^{52} \mathrm{Cr},{ }^{60} \mathrm{Ni},{ }^{69} \mathrm{Ga},{ }^{88} \mathrm{Sr},{ }^{90} \mathrm{Zr},{ }^{139} \mathrm{La},{ }^{140} \mathrm{Ce}$, ${ }^{146} \mathrm{Nd},{ }^{147} \mathrm{Sm},{ }^{151} \mathrm{Eu},{ }^{161} \mathrm{Dy},{ }^{167} \mathrm{Er},{ }^{172} \mathrm{Yb},{ }^{175} \mathrm{Lu}$ and ${ }^{178} \mathrm{Hf}$. A gas blank was run before each measurement. Raw data were processed using Iolite 3.5 (Paton et al., 2011) with standard reference values for NIST 612 (Pearce et al., 1997) and the concentrations of ${ }^{29} \mathrm{Si}$ and ${ }^{44} \mathrm{Ca}$ determined by electron probe as internal standards. NIST 610 was measured intermittently to monitor precision and accuracy, which is estimated as $\sim 5 \%$. A complete listing of major and trace element analyses of clinopyroxene and plagioclase is provided in the Supplement (S2 and S3). Examination and analysis of symplectites and oxides were done with a JEOL 6400 scanning electron microscope with an EDAX energy dispersive $\mathrm{X}$-ray analysis system. Analyses were made at an accelerating voltage of $15 \mathrm{kV}$, beam current of $1 \mathrm{nA}$ and count times of $60 \mathrm{~s}$.

\section{Petrography and classification}

The five granulite xenoliths (Table 1) found in the SEL deposits are rounded to oblate spheroids with a maximum diameter of $5 \mathrm{~cm}$. One sample is massive; four are layered. Three of the xenoliths have fine-grained, symplectic intergrowths of orthopyroxene, hercynite and calcic plagioclase (Fig. 2a, b). Analyses of 100 by $100 \mu \mathrm{m}$ areas of these symplectites and recombination of the phases based on their modal abundance and composition (Table 2) indicate that they have the approximate composition of garnet (almandine: 41-48 mole \%; andradite/grossular: 16-22 mole \%; and pyrope: $23-26$ mole $\%$ ). The interpretation of the symplectites as the product of garnet is supported by their shape and the similarity in texture with experimentally produced garnet breakdown (Obata et al., 2014). Hereafter, references to garnet in the observed phase assemblage refer to the interpretation of the original nature of the symplectites.

The layers in the xenoliths are 0.5 to $1 \mathrm{~cm}$ thick and are defined by variations in the proportion of plagioclase and clinopyroxene in three samples and by the presence of the breakdown products of garnet in the fourth. The grain size of the main phases in the xenoliths is $1-2 \mathrm{~mm}$.

All five samples are mafic granulites. Three (10E, 13E and $13 \mathrm{H})$ consist of garnet, plagioclase and clinopyroxene with lesser quartz and scapolite. Garnet breakdown products occur in fine-grained black layers, and accessory titanite is common. The two garnet-free samples are dominated
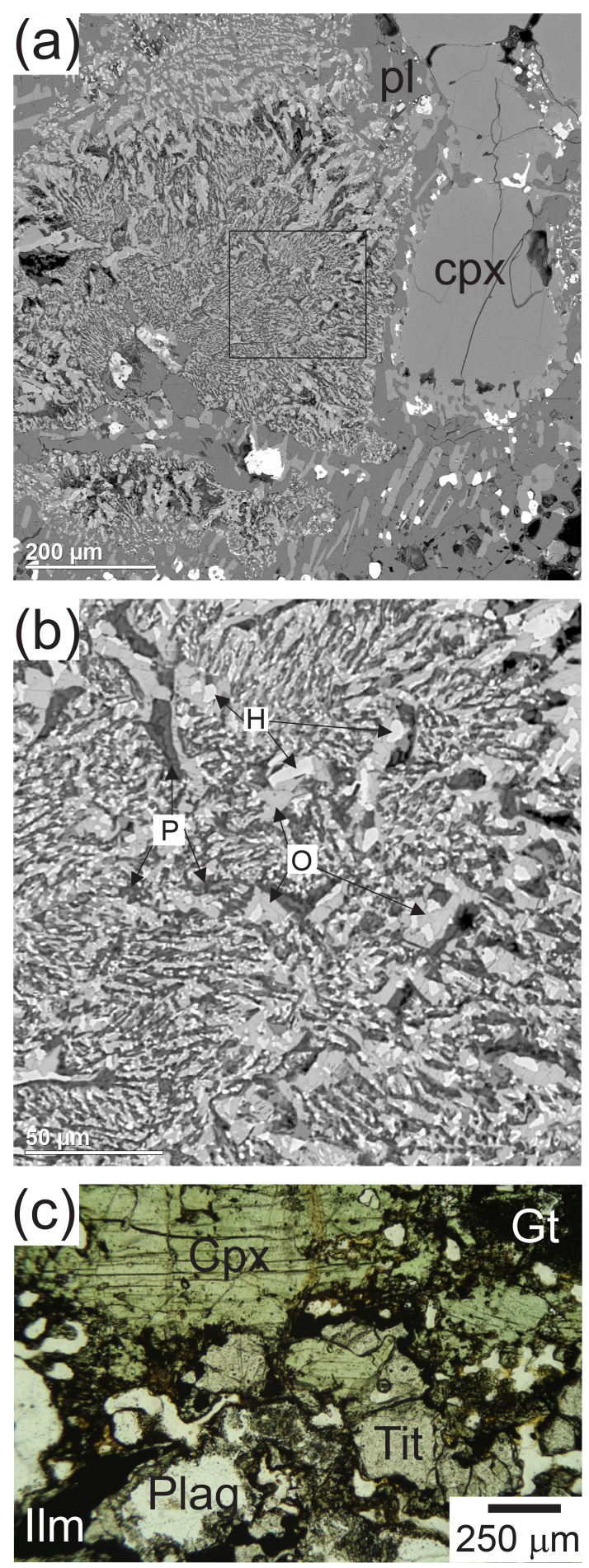

Figure 2. (a) Backscattered electron image of sample 13H showing a pseudomorph after garnet surrounded by calcic plagioclase. Right side of the image shows a coarse clinopyroxene decorated with neoblasts of clinopyroxene. The region in the pseudomorph outlined by the square is shown in more detail in panel (b). (b) Intergrowth of hercynite $(\mathrm{H})$, orthopyroxene $(\mathrm{O})$ and plagioclase $(\mathrm{P})$ in garnet pseudomorph. (c) Photomicrograph of sample 10E showing titanite (Tit) intergrown with plagioclase (Plag), ilmenite (Ilm) and clinopyroxene (Cpx). Garnet breakdown products are visible in the top right of the image. 
Table 1. Sample description and summary of age data.

\begin{tabular}{|c|c|c|c|}
\hline Sample & Texture and mineralogy & Clinopyroxene composition & Age (Myr) \\
\hline \multicolumn{4}{|c|}{ Type 1 clinopyroxene } \\
\hline $11 \mathrm{~L}$ & $\begin{array}{l}1-2 \mathrm{~cm} \text { thick layers. Plagioclase, clinopyrox- } \\
\text { ene, oxides, titanite, trace quartz and trace al- } \\
\text { tered biotite. }\end{array}$ & $\begin{array}{l}\text { Chondrite-normalised REE abundances be- } \\
\text { tween } 1 \text { and } 10 \text { times chondrite. Patterns are } \\
\text { flat. Primitive mantle-normalised multi-element } \\
\text { plots show a positive Hf anomaly. }\end{array}$ & $259.4 \pm 4.7$ \\
\hline $13 \mathrm{E}$ & $\begin{array}{l}1 \mathrm{~cm} \text { layers, garnet breakdown products present } \\
\text { in one layer near the edge of the xenolith. } \\
\text { Plagioclase, clinopyroxene, scapolite, oxides, } \\
\text { quartz and titanite. }\end{array}$ & & $266.2 \pm 1.4$ \\
\hline \multicolumn{4}{|c|}{ Type 2 clinopyroxene } \\
\hline $10 \mathrm{E}$ & $\begin{array}{l}1-2 \mathrm{~cm} \text { thick layers defined by garnet break- } \\
\text { down products. Clinopyroxene, plagioclase, } \\
\text { quartz, titanite and scapolite. }\end{array}$ & $\begin{array}{l}\text { Chondrite-normalised REE patterns show en- } \\
\text { richment in Pr to Dy. HREE abundances are } \\
\text { variable, ranging from sub-chondritic to } \sim 20 \\
\text { times chondrite. }\end{array}$ & $253.7 \pm 2.5$ \\
\hline $13 \mathrm{H}$ & $\begin{array}{l}\text { Massive. Clinopyroxene, plagioclase, oxides, } \\
\text { quartz and garnet breakdown products. }\end{array}$ & $\begin{array}{l}\text { Primitive mantle-normalised multi-element } \\
\text { plots show negative } \mathrm{Sr}, \mathrm{Zr} \text { and } \mathrm{Ti} \text { anomalies. }\end{array}$ & \\
\hline $10 \mathrm{~L}$ & $\begin{array}{l}\text { Diffuse layering } \sim 0.5 \mathrm{~mm} \text { thick. Plagioclase, } \\
\text { clinopyroxene, oxides, quartz and trace titanite. }\end{array}$ & & \\
\hline
\end{tabular}

Table 2. Phases in symplectite in sample $13 \mathrm{H}$ - energy dispersion spectroscopy (EDS) analyses.

\begin{tabular}{lrrrrrrrrrrrr}
\hline wt $\%$ & Hercy & Hercy & Opx & Opx & Opx & Opx & An & An & An & Area scan & Area scan & Mode \\
\hline $\mathrm{SiO}_{2}$ & 0.36 & 1.54 & 45.66 & 48.93 & 50.38 & 50.56 & 45.10 & 44.39 & 47.70 & 38.50 & 41.32 & 38.23 \\
$\mathrm{TiO}_{2}$ & 0.12 & 0.85 & 0.00 & 0.06 & 0.32 & 0.24 & 0.06 & 0.00 & 0.00 & 0.34 & 0.45 & 0.16 \\
$\mathrm{Al}_{2} \mathrm{O}_{3}$ & 47.88 & 39.05 & 7.16 & 3.77 & 4.52 & 4.87 & 35.61 & 34.99 & 32.91 & 24.69 & 26.29 & 26.43 \\
$\mathrm{FeO}$ & 42.97 & 49.33 & 33.15 & 28.60 & 20.83 & 19.79 & 1.51 & 1.99 & 1.22 & 21.54 & 15.74 & 18.16 \\
$\mathrm{MnO}$ & 0.79 & 0.58 & 1.37 & 1.32 & 0.84 & 0.68 & 0.09 & 0.17 & 0.14 & 0.85 & 0.40 & 0.55 \\
$\mathrm{MgO}$ & 7.44 & 8.00 & 9.80 & 15.28 & 20.81 & 21.09 & 0.29 & 0.36 & 0.30 & 6.89 & 5.13 & 7.23 \\
$\mathrm{CaO}$ & 0.09 & 2.48 & 2.56 & 1.70 & 1.88 & 2.48 & 16.44 & 16.88 & 15.30 & 6.37 & 9.30 & 8.45 \\
$\mathrm{Na} 2 \mathrm{O}$ & 0.22 & 0.24 & 0.00 & 0.11 & 0.13 & 0.07 & 0.81 & 0.89 & 2.35 & 0.58 & 0.89 & 0.71 \\
$\mathrm{~K}_{2} \mathrm{O}$ & 0.04 & 0.09 & 0.07 & 0.03 & 0.09 & 0.07 & 0.06 & 0.15 & 0.08 & 0.26 & 0.21 & 0.08 \\
\hline Total & 99.92 & 99.92 & 99.76 & 99.80 & 99.81 & 99.83 & 100.01 & 99.81 & 99.99 & 100.01 & 99.74 & 99.99 \\
\hline
\end{tabular}

Hercy: hercynite. Opx: orthopyroxene. An: plagioclase. Area scan: scan of a $100 \times 100 \mu \mathrm{m}$ region at the centre of two different symplectite regions. Mode: composition based on recombination of the average composition of each mineral phase in the proportions $19.2 \%$ hercynite, $33.4 \%$ orthopyroxene and $47.5 \%$ anorthite (determined from image analysis of Fig. 2c).

by clinopyroxene and plagioclase with lesser quartz and titanite. One sample has traces of altered biotite. Plagioclase in all the samples shows evidence of deformation: lenticular, kinked and offset twin lamellae (Vernon, 2004). Where present, quartz shows well-developed undulose extinction. Both plagioclase and quartz contain numerous fluid inclusions. Scapolite partly to completely replaces plagioclase in samples $10 \mathrm{E}$ and $13 \mathrm{H}$. Clinopyroxene is green, anhedral, strongly pleochroic and unzoned, though the cores of most grains are rich in fluid and opaque inclusions. The $\mathrm{Fe}-\mathrm{Ti}$ oxides are two phase, with a hercynite and ulvöspinel phase. Titanite forms $0.2-0.8 \mathrm{~mm}$ anhedral grains interstitial to plagioclase, clinopyroxene and $\mathrm{Fe}-\mathrm{Ti}$ oxides (Fig. 2c).

\section{Mineral compositions}

\subsection{Clinopyroxene}

Clinopyroxene in the xenoliths is aluminian diopside (Table 3), though each sample defines a distinct cluster of compositions in terms of $\mathrm{xMg}$ [molar $\mathrm{Mg} /\left(\mathrm{Mg}+\mathrm{Fe}^{\text {tot }}\right)$. 100]. Clinopyroxene in garnet-free granulites shows rimcore zonation; rims are typically slightly more magnesian and less sodic than cores. Overall, clinopyroxene shows increasing $\mathrm{TiO}_{2}, \mathrm{Al}_{2} \mathrm{O}_{3}$ and to a lesser extent $\mathrm{Na}_{2} \mathrm{O}$ with decreasing $\mathrm{xMg}($ Fig. 3a-c). Clinopyroxene in the garnetbearing samples overlaps in composition with that in the garnet-free samples but extends to higher $\mathrm{xMg}$ (Fig. 3). 

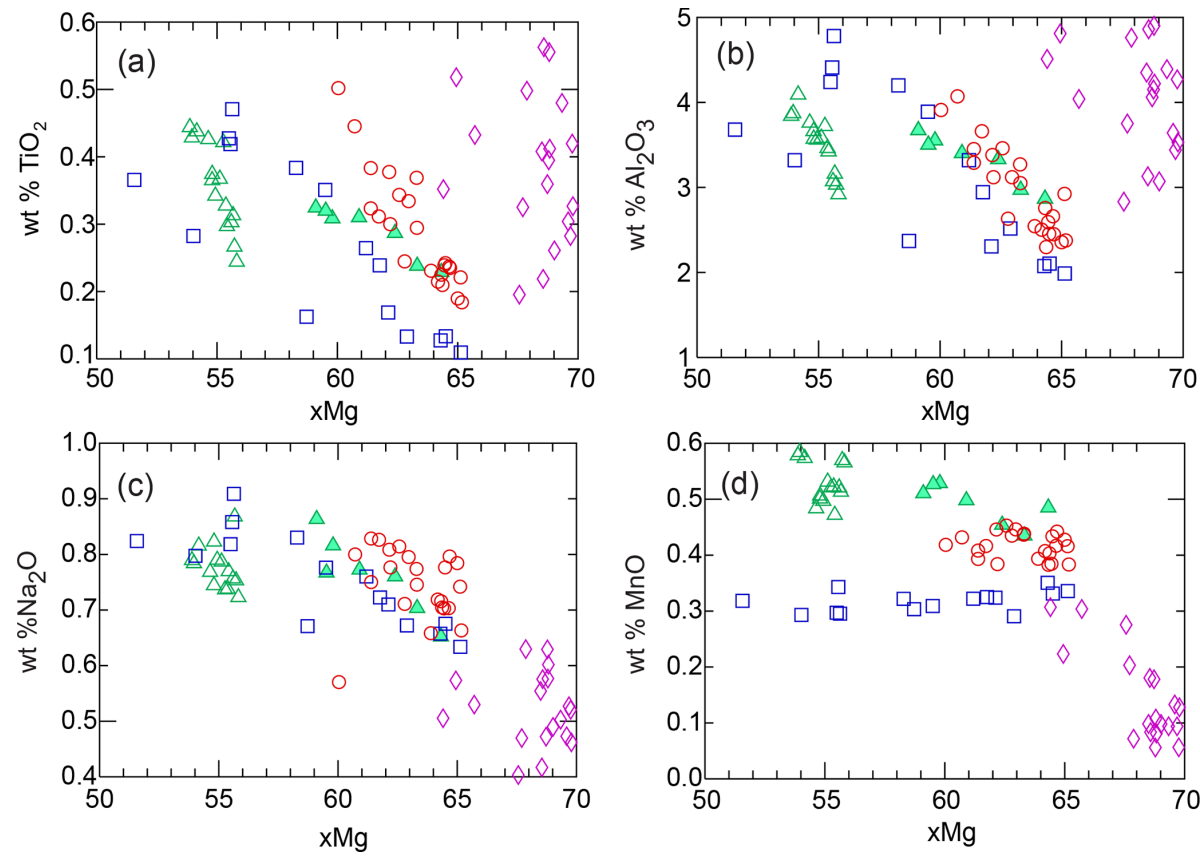

Figure 3. Major element composition of clinopyroxene. (a) $\mathrm{xMg}$ vs. weight percent $\mathrm{TiO}_{2}$. (b) $\mathrm{xMg}$ vs. weight percent $\mathrm{Al}_{2} \mathrm{O}_{3}$. (c) $\mathrm{xMg}$ vs. weight percent $\mathrm{Na}_{2} \mathrm{O}$. (d) $\mathrm{xMg}$ vs. weight percent $\mathrm{MnO}$.

The same trends of increasing $\mathrm{TiO}_{2}, \mathrm{Al}_{2} \mathrm{O}_{3}$ and $\mathrm{Na}_{2} \mathrm{O}$ with decreasing $\mathrm{xMg}$ are seen in these samples; however, the clinopyroxene in garnet-bearing samples is depleted in $\mathrm{MnO}$ (Fig. 3a-d).

On the basis of the trace element composition of clinopyroxene the samples can be subdivided into two groups (Table 3, Fig. 4). Type 1 has one garnet-free and one garnetbearing sample (11L and 13E respectively). Clinopyroxene in these samples shows nearly flat chondrite-normalised REE profiles and a distinct positive $\mathrm{Hf}$ anomaly on a primitive mantle-normalised multi-element plot. The garnetfree sample has low Co $(<20 \mathrm{ppm})$ and high Sc $(40$ $80 \mathrm{ppm})$ and $\mathrm{Cr}(100-200 \mathrm{ppm})$ compared to the garnetbearing sample. Type 2 clinopyroxene also occurs in garnetfree $(10 \mathrm{~L})$ and garnet-bearing samples $(10 \mathrm{E}$ and $13 \mathrm{H})$. In these samples, clinopyroxene has convex upward chondritenormalised REE patterns with moderate light-REE (LREE) depletion compared to middle REE (MREE). Clinopyroxene in the garnet-free samples has 20-30 times chondrite heavy REE (HREE). The two garnet-bearing samples have clinopyroxene with a much wider range of HREE content, from strongly depleted with convex upward to flat REE patterns similar to those of the garnet-free sample. Type 2 clinopyroxene is also distinct from type 1 clinopyroxene in the negative $\mathrm{Sr}, \mathrm{Zr}$ and $\mathrm{Ti}$ anomalies on the primitive mantle-normalised multi-element plot.

Several samples show small variations in trace element composition across the clinopyroxene crystals (Fig. 5). There is minor zonation in $\mathrm{Ti}$ and $\mathrm{Zr}$, with cores slightly enriched relative to rims. In the garnet-bearing samples, $\mathrm{Yb}$ and the other heavy rare earth elements are enriched at the edge of the crystals, where they are in contact with the garnet breakdown products (Fig. 5a, c). In contrast, clinopyroxene rims in the garnet-free sample are HREE depleted.

\subsection{Plagioclase}

Garnet-free granulites 10L and 11L have average plagioclase compositions of $\mathrm{An}_{45}$ and $\mathrm{An}_{42}$ respectively, and the garnetbearing sample (10E) has plagioclase of $\mathrm{An}_{46}$ (Fig. 6a). In contrast, the other two garnet-bearing samples have much more calcic plagioclase (13E: $\mathrm{An}_{66} ; 13 \mathrm{H}$ : An 80 ; Table 4). The anorthite content of plagioclase has a positive correlation with the $\mathrm{xMg}$ of clinopyroxene.

In the symplectites, the plagioclase is $A_{90}$. Unlike the coarser plagioclase in the layers, the plagioclase in the symplectites contains up to $2 \mathrm{wt} \% \mathrm{FeO}$ (Table 2).

The three samples for which trace elements were determined show a variable positive Eu anomaly, small in $11 \mathrm{~L}$ and large in $13 \mathrm{H}$ with $10 \mathrm{~L}$ intermediate (Fig. $6 \mathrm{~b}$ ). Sample $11 \mathrm{~L}$ is distinct in its $\mathrm{Sr}$ enrichment (Table 4), which correlates with the Sr-rich composition of coexisting clinopyroxene.

\subsection{Oxides}

The abundant oxide grains in sample $13 \mathrm{H}$ have cores of ilmenite mantled by ulvöspinel (Table 5). In the symplectites, the oxide is hercynite (Table 2). 
Table 3. Major and trace element of clinopyroxene.

\begin{tabular}{|c|c|c|c|c|c|c|c|c|c|c|}
\hline Sample & $11 \mathrm{~L}$ & $11 \mathrm{~L}$ & $13 \mathrm{E}$ & $13 \mathrm{E}$ & $10 \mathrm{E}$ & $10 \mathrm{E}$ & $13 \mathrm{H}$ & $13 \mathrm{H}$ & $10 \mathrm{~L}$ & $10 \mathrm{~L}$ \\
\hline type & 1 & 1 & 1 & 1 & 2 & 2 & 2 & 2 & 2 & 2 \\
\hline \multicolumn{11}{|l|}{ wt $\%$} \\
\hline $\mathrm{SiO}_{2}$ & 49.27 & 49.64 & 50.16 & 49.78 & 49.91 & 49.71 & 49.71 & 49.90 & 51.14 & 50.83 \\
\hline $\mathrm{TiO}_{2}$ & 0.44 & 0.36 & 0.43 & 0.37 & 0.22 & 0.21 & 0.33 & 0.52 & 0.23 & 0.32 \\
\hline $\mathrm{Al}_{2} \mathrm{O}_{3}$ & 3.84 & 3.66 & 4.24 & 3.68 & 2.92 & 2.30 & 3.75 & 4.81 & 2.86 & 3.50 \\
\hline $\mathrm{Cr}_{2} \mathrm{O}_{3}$ & 0.03 & 0.03 & 0.01 & 0.03 & 0.03 & 0.04 & 0.01 & 0.02 & 0.02 & 0.01 \\
\hline $\mathrm{FeO}$ & 13.94 & 13.80 & 13.56 & 15.31 & 11.13 & 11.15 & 10.73 & 11.46 & 11.43 & 12.46 \\
\hline $\mathrm{MnO}$ & 0.58 & 0.50 & 0.30 & 0.32 & 0.42 & 0.40 & 0.20 & 0.22 & 0.48 & 0.53 \\
\hline $\mathrm{MgO}$ & 9.13 & 9.38 & 9.48 & 9.14 & 11.65 & 11.29 & 12.61 & 11.90 & 11.55 & 10.27 \\
\hline $\mathrm{CaO}$ & 21.78 & 22.28 & 22.27 & 21.32 & 21.62 & 22.88 & 21.38 & 20.65 & 21.90 & 22.24 \\
\hline $\mathrm{Na}_{2} \mathrm{O}$ & 0.79 & 0.74 & 0.82 & 0.82 & 0.74 & 0.70 & 0.47 & 0.57 & 0.65 & 0.77 \\
\hline Total & 99.80 & 100.4 & 101.26 & 100.76 & 98.64 & 98.68 & 99.19 & 98.06 & 100.27 & 100.92 \\
\hline \multicolumn{11}{|l|}{ ppm } \\
\hline $\mathrm{Sc}$ & 51.4 & 52.8 & 27.3 & 65.3 & 37.9 & 45.6 & 90.7 & 79.7 & 77.2 & 49.6 \\
\hline $\mathrm{Ti}$ & 1642 & 1641 & 2033 & 2117 & 1103 & 1091 & 1638 & 2229 & 1878 & 1251 \\
\hline $\mathrm{V}$ & 213 & 214 & 321 & 303 & 235 & 210 & 284 & 416 & 373 & 285 \\
\hline $\mathrm{Cr}$ & 145 & 125 & 21 & 78 & 48 & 18 & 181 & 197 & 51 & 26 \\
\hline $\mathrm{Co}$ & 14.4 & 12.8 & 57.8 & 71.5 & 35.8 & 31.9 & 77.8 & 78.2 & 63.4 & 44.4 \\
\hline $\mathrm{Ni}$ & 9.7 & 6.3 & 79.9 & 70.7 & 46.8 & 44.1 & 147.2 & 143.3 & 84.7 & 57.3 \\
\hline $\mathrm{Rb}$ & 0.03 & bdl & 0.24 & bdl & 0.19 & bdl & 0.45 & 0.10 & 0.02 & 0.01 \\
\hline $\mathrm{Sr}$ & 42.6 & 35.1 & 46.9 & 52.1 & 9.8 & 11.3 & 11.2 & 15.0 & 24.2 & 13.2 \\
\hline $\mathrm{Y}$ & 2.3 & 2.8 & 4.3 & 4.0 & 14.0 & 5.1 & 18.8 & 12.5 & 57.7 & 34.5 \\
\hline $\mathrm{Zr}$ & 35.2 & 39.4 & 56.3 & 45.8 & 25.2 & 16.0 & 20.1 & 40.0 & 47.7 & 25.6 \\
\hline $\mathrm{Nb}$ & 0.01 & bdl & 0.19 & bdl & 0.27 & 0.01 & 0.35 & 0.17 & 0.10 & 0.03 \\
\hline $\mathrm{La}$ & 1.28 & 0.54 & 0.56 & 0.66 & 0.62 & 0.99 & 2.26 & 1.74 & 0.74 & 0.69 \\
\hline $\mathrm{Ce}$ & 2.95 & 1.83 & 2.40 & 1.86 & 1.39 & 3.32 & 8.98 & 6.15 & 8.26 & 2.51 \\
\hline $\operatorname{Pr}$ & 0.39 & 0.32 & 0.43 & 0.32 & 0.34 & 0.50 & 1.66 & 1.30 & 2.73 & 0.76 \\
\hline $\mathrm{Nd}$ & 1.91 & 2.13 & 2.29 & 1.43 & 3.40 & 2.56 & 9.58 & 10.82 & 21.17 & 7.59 \\
\hline $\mathrm{Sm}$ & 0.46 & 0.56 & 0.56 & 0.61 & 1.83 & 0.72 & 3.77 & 4.72 & 8.83 & 4.69 \\
\hline $\mathrm{Eu}$ & 0.10 & 0.12 & 0.16 & 0.14 & 0.48 & 0.27 & 1.41 & 1.56 & 2.25 & 1.30 \\
\hline $\mathrm{Gd}$ & 0.38 & 0.66 & 0.72 & 0.72 & 2.84 & 1.08 & 4.54 & 5.68 & 11.54 & 6.50 \\
\hline $\mathrm{Tb}$ & 0.08 & 0.09 & 0.12 & 0.11 & 0.49 & 0.24 & 0.76 & 0.70 & 1.94 & 1.18 \\
\hline Dy & 0.41 & 0.61 & 0.76 & 0.53 & 3.11 & 1.13 & 4.32 & 3.45 & 12.14 & 7.40 \\
\hline Ho & 0.08 & 0.10 & 0.18 & 0.13 & 0.61 & 0.20 & 0.71 & 0.53 & 2.50 & 1.49 \\
\hline $\mathrm{Er}$ & 0.22 & 0.33 & 0.43 & 0.43 & 1.27 & 0.41 & 1.76 & 0.86 & 6.04 & 3.72 \\
\hline $\mathrm{Tm}$ & 0.03 & 0.03 & 0.06 & 0.06 & 0.17 & 0.05 & 0.24 & 0.13 & 0.74 & 0.50 \\
\hline $\mathrm{Yb}$ & 0.38 & 0.28 & 0.50 & 0.47 & 1.12 & 0.41 & 1.42 & 0.59 & 5.49 & 3.22 \\
\hline $\mathrm{Lu}$ & 0.07 & 0.07 & 0.12 & 0.12 & 0.18 & 0.07 & 0.22 & 0.06 & 0.78 & 0.53 \\
\hline $\mathrm{Hf}$ & 1.65 & 1.78 & 2.17 & 2.45 & 1.83 & 1.47 & 1.72 & 2.84 & 3.16 & 1.75 \\
\hline
\end{tabular}

bdl: below detection limits.

\section{Geothermometry}

The temperature of equilibration of the xenoliths has been calculated using three independent methods: the Mg-inplagioclase thermometer of Faak et al. (2013), for samples with plagioclase more calcic than $\mathrm{An}_{50}$; the REE-inplagioclase-clinopyroxene thermometer of Sun and Liang (2017); and the Zr-in-titanite thermometer (Hayden et al., 2008). The results are summarised in Table 6. The temperature calculated using the Mg-in-plagioclase thermometer is significantly lower than that calculated using the REE-in- plagioclase-clinopyroxene thermometer. The faster diffusion of Mg compared to REE in plagioclase (Faak et al., 2013; Sun and Liang, 2017) gives a higher closure temperature for the REE-in-plagioclase-clinopyroxene geothermometer, which may record the original crystallisation temperature. Conversely, because of its lower closure temperature, $\mathrm{Mg}$ in plagioclase is more likely to record a metamorphic equilibration temperature. The temperature determined from REE in plagioclase ranges from 1090 to $1330^{\circ} \mathrm{C}$, i.e. a magmatic temperature range, whereas $\mathrm{Mg}$ in plagioclase gives tempera- 

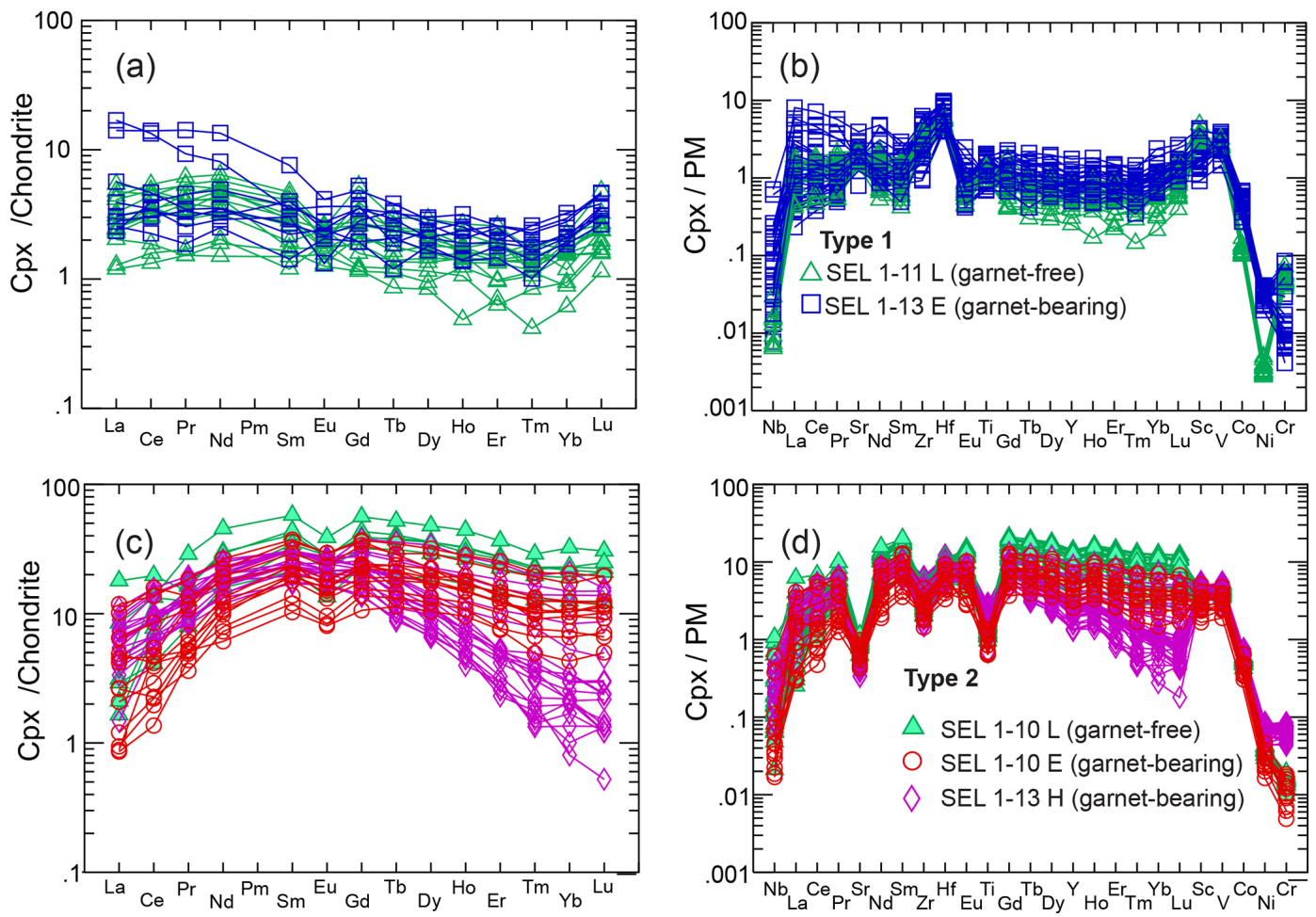

Figure 4. Chondrite-normalised rare earth element and primitive mantle normalised incompatible element patterns for clinopyroxene. Normalisation factors from Sun and McDonough (1989). (a) Chondrite-normalised rare earth element plot of type 1 clinopyroxene. (b) Primitive mantle-normalised multi-element plot type 1 clinopyroxene. (c) Chondrite-normalised rare earth element plot type 2 clinopyroxene. (d) Primitive mantle-normalised multi-element plot of type 2 clinopyroxene.

ture in the range 680 to $930{ }^{\circ} \mathrm{C}$, which is closer to the temperature expected for equilibration of lower-crustal granulites in this region (Loock et al., 1990).

Zirconium contents in the titanites are extremely variable. In sample 13E, $\mathrm{Zr}$ contents range between 163 and $1483 \mathrm{ppm}$ with an average of $968 \mathrm{ppm}$. Samples 11L and 10E have smaller ranges and average $\mathrm{Zr}$ contents of 641 and $517 \mathrm{ppm}$ respectively. Application of the $\mathrm{Zr}$-in-titanite thermometer gives temperatures ranging from 783 to $818^{\circ} \mathrm{C}$. These temperatures were calculated for titanite in quartz-bearing samples assuming both $\mathrm{aSiO}_{2}$ and $\mathrm{aTiO}_{2}$ set to unity. Slightly lower activities will give temperatures that are lower by 10 $20^{\circ} \mathrm{C}$. Samples $11 \mathrm{~L}$ and $13 \mathrm{H}$ have a unimodal temperature distribution with maxima at $800-810$ and $820-830^{\circ} \mathrm{C}$ respectively. Sample 10E gives a bimodal temperature distribution with maxima at 780 and $810^{\circ} \mathrm{C}$. The $\mathrm{Zr}$-in-titanite temperature range overlaps with those of $\mathrm{Mg}$ in plagioclase, indicating that both record lower-crustal equilibration temperature for the xenoliths.

\section{Geochronology}

$\mathrm{U}-\mathrm{Pb}$ data for titanite in three samples (Fig. 7, Supplement S1) define a broad array in Tera-Wasserburg plots. The upper intercept ages of the three samples do not overlap, but all are upper Permian (253-266 Myr). The lower intercept ages range from Triassic to late Miocene (Fig. 7).

The lack of overlap (within the error bounds of the age determinations) suggests that the xenoliths represent samples from at least two distinct sources: one with an age of $\sim 264 \mathrm{Myr}$ (11L and 13E) and a second of $\sim 253 \mathrm{Myr}(10 \mathrm{E})$, in agreement with different REE signatures of clinopyroxene. Frost et al. (2001) and Hartnady et al. (2019) proposed that the closure temperature of titanite is above 660 and possibly above $800^{\circ} \mathrm{C}$. The temperatures determined from the $\mathrm{Zr}$-in-titanite and $\mathrm{Mg}$-in-plagioclase thermometers suggest that the titanites may have been close to or above their closure temperature. This is in accord with the wide spread of the data on Tera-Wasserburg plots, suggesting that there has been significant resetting of the $\mathrm{U}-\mathrm{Pb}$ systematics due to lead loss during reheating events. The probability density plot (Fig. 7d) suggests a major disturbance at 230-200 Ma with almost continuous disturbance occurring to $\sim 6 \mathrm{Ma}$ with a gap between 20 and $30 \mathrm{Ma}$. Even though there is some possible reheating, Hartnady et al. (2019) suggested that the extremely low diffusivity of $\mathrm{Pb}$ implies that titanite can be used to reliably date its crystallisation. This is discussed in more detail below. 
Table 4. Major and trace element composition of plagioclase.

\begin{tabular}{lrrrrrrrrr}
\hline Sample & $11 \mathrm{~L}$ & $11 \mathrm{~L}$ & $13 \mathrm{E}$ & $10 \mathrm{E}$ & $10 \mathrm{E}$ & $13 \mathrm{H}$ & $13 \mathrm{H}$ & $10 \mathrm{~L}$ & $10 \mathrm{~L}$ \\
\hline $\mathrm{wt} \%$ & & & & & & & & & \\
\hline $\mathrm{SiO}_{2}$ & 57.49 & 57.05 & 53.13 & 55.97 & 56.10 & 46.35 & 47.90 & 57.22 & 55.87 \\
$\mathrm{Al}_{2} \mathrm{O}_{3}$ & 25.91 & 26.55 & 28.25 & 28.08 & 27.26 & 34.55 & 32.93 & 26.98 & 26.22 \\
$\mathrm{FeO}$ & 0.10 & 0.37 & 0.59 & 0.09 & 0.18 & 0.39 & 0.32 & 0.12 & 0.38 \\
$\mathrm{MnO}$ & 0.00 & 0.01 & bdl & 0.01 & 0.04 & 0.01 & bdl & bdl & bdl \\
$\mathrm{CaO}$ & 8.53 & 9.15 & 11.92 & 9.69 & 9.88 & 17.49 & 15.59 & 8.95 & 9.63 \\
$\mathrm{Na}{ }_{2} \mathrm{O}$ & 6.76 & 6.35 & 4.58 & 6.14 & 5.73 & 1.67 & 2.66 & 6.29 & 5.97 \\
$\mathrm{~K} 2 \mathrm{O}$ & 0.42 & 0.59 & 0.48 & 0.41 & 0.55 & 0.04 & 0.03 & 0.36 & 0.34 \\
$\mathrm{total}$ & 99.22 & 100.07 & 98.96 & 100.39 & 99.75 & 100.50 & 99.42 & 99.92 & 98.40 \\
\hline $\mathrm{ppm}$ & & & & & & & & & \\
\hline $\mathrm{Ti}$ & 197 & 285 & na & na & na & 14 & 18 & 29 & 11 \\
$\mathrm{Sr}$ & 1854 & 1977 & na & na & na & 357 & 548 & 800 & 747 \\
$\mathrm{Y}$ & 0.53 & 0.76 & na & na & na & 0.84 & 0.39 & 0.07 & 0.18 \\
$\mathrm{La}$ & 2.15 & 2.96 & na & na & na & 2.82 & 2.42 & 2.47 & 1.98 \\
$\mathrm{Ce}$ & 1.75 & 2.14 & na & na & na & 5.81 & 3.81 & 3.64 & 3.17 \\
$\mathrm{Pr}$ & 0.20 & 0.22 & na & na & na & 0.48 & 0.31 & 0.32 & 0.24 \\
$\mathrm{Nd}$ & 0.84 & 1.08 & na & na & na & 1.73 & 1.09 & 1.15 & 0.80 \\
$\mathrm{Sm}$ & 0.04 & 0.14 & na & na & na & 0.22 & 0.15 & bdl & bdl \\
$\mathrm{Eu}$ & 0.04 & 0.12 & na & na & na & 0.56 & 0.54 & 0.14 & 0.28 \\
$\mathrm{Gd}$ & 0.11 & bdl & na & na & na & 0.11 & bdl & bdl & bdl \\
$\mathrm{Tb}$ & bdl & 0.01 & na & na & na & 0.03 & bdl & bdl & bdl \\
$\mathrm{Dy}$ & 0.07 & 0.14 & na & na & na & bdl & bdl & bdl & bdl \\
$\mathrm{Ho}$ & 0.02 & 0.02 & na & na & na & 0.02 & bdl & bdl & 0.01 \\
$\mathrm{Er}$ & 0.03 & 0.08 & na & na & na & 0.04 & bdl & bdl & bdl \\
$\mathrm{Tm}$ & bdl & bdl & na & na & na & bdl & bdl & bdl & bdl \\
$\mathrm{Yb}$ & 0.08 & bdl & na & na & na & bdl & bdl & bdl & bdl \\
$\mathrm{Lu}$ & bdl & 0.03 & na & na & na & bdl & bdl & bdl & bdl \\
\hline & & & & & & & & &
\end{tabular}

bdl: below detection limits; na: not analysed.

Table 5. Ilmenite and Ulvöspinel analysis (EDS) from sample 1-13H.

\begin{tabular}{lrrrrrrrr}
\hline wt \% & Ilm & Ulvsp & Ilm & Ulvsp & Ilm & Ulvsp & Ilm & Ulvsp \\
\hline $\mathrm{SiO}_{2}$ & 0.19 & 0.23 & 0.22 & 0.11 & 0.19 & 0.18 & 0.18 & 0.25 \\
$\mathrm{TiO}_{2}$ & 42.39 & 22.00 & 43.66 & 22.51 & 41.21 & 12.83 & 41.81 & 19.11 \\
$\mathrm{Al}_{2} \mathrm{O}_{3}$ & 0.96 & 3.04 & 0.82 & 3.06 & 0.91 & 6.42 & 0.98 & 4.85 \\
$\mathrm{FeO}$ & 52.97 & 70.98 & 51.45 & 69.91 & 54.27 & 76.74 & 53.58 & 71.29 \\
$\mathrm{MnO}$ & 0.67 & 0.81 & 0.50 & 0.77 & 0.50 & 0.66 & 0.56 & 0.60 \\
$\mathrm{MgO}$ & 2.54 & 2.69 & 3.01 & 3.31 & 2.57 & 2.81 & 2.63 & 3.41 \\
$\mathrm{CaO}$ & 0.09 & 0.04 & 0.21 & 0.18 & 0.17 & 0.13 & 0.09 & 0.24 \\
$\mathrm{Na}_{2} \mathrm{O}$ & 0.07 & 0.00 & 0.00 & 0.00 & 0.00 & 0.00 & 0.00 & 0.00 \\
$\mathrm{Total}$ & 99.88 & 99.78 & 99.86 & 99.85 & 99.82 & 99.78 & 99.83 & 99.75 \\
\hline
\end{tabular}

Ilm: ilmenite; Ulvsp: ulvöspinel.

\section{Discussion}

\subsection{Nature of the protolith}

The high temperature recorded by REE-in-plagioclaseclinopyroxene thermometry suggests that these xenoliths preserve at least part of an original igneous mineralogy, whereas the lower temperature from $\mathrm{Mg}$-in-plagioclase and Zr-in-titanite thermometry may record the equilibration temperature at the base of the crust. The orthopyroxeneplagioclase-hercynite symplectites attest to the breakdown of pre-existing garnet. This leads to the question of whether these xenoliths should be considered truly metamorphic or whether they are lower-crustal cumulates that crystallised ig- 
Table 6. Summary of mineral thermometry results (in ${ }^{\circ} \mathrm{C}$ ).

\begin{tabular}{lrrrr}
\hline \multirow{2}{*}{ Sample } & \multicolumn{4}{c}{ Method } \\
\cline { 2 - 4 } & REE in plagioclase & \multicolumn{2}{c}{ Mg exchange } & Zr in titanite \\
\cline { 2 - 3 } & & $\mathrm{aSiO}_{2}=1$ & $\mathrm{aSiO}_{2}=0.64$ & \\
\cline { 2 - 4 } & Sun and Liang (2017) & \multicolumn{2}{c}{ Faak et al. (2013) } & Hayden et al. (2008) \\
\hline $11 \mathrm{~L}$ & $1268 \pm 47$ & $856 \pm 39$ & $927 \pm 44$ & $799 \pm 9$ \\
$10 \mathrm{E}$ & n.d. & n.d. & n.d. & $783 \pm 25$ \\
$13 \mathrm{H}$ & $1331 \pm 71$ & $725 \pm 28$ & $788 \pm 31$ & $818 \pm 24$ \\
$10 \mathrm{~L}$ & $1089 \pm 71$ & $632 \pm 114$ & $679 \pm 126$ & n.d. \\
\hline
\end{tabular}

n.d.: not determined
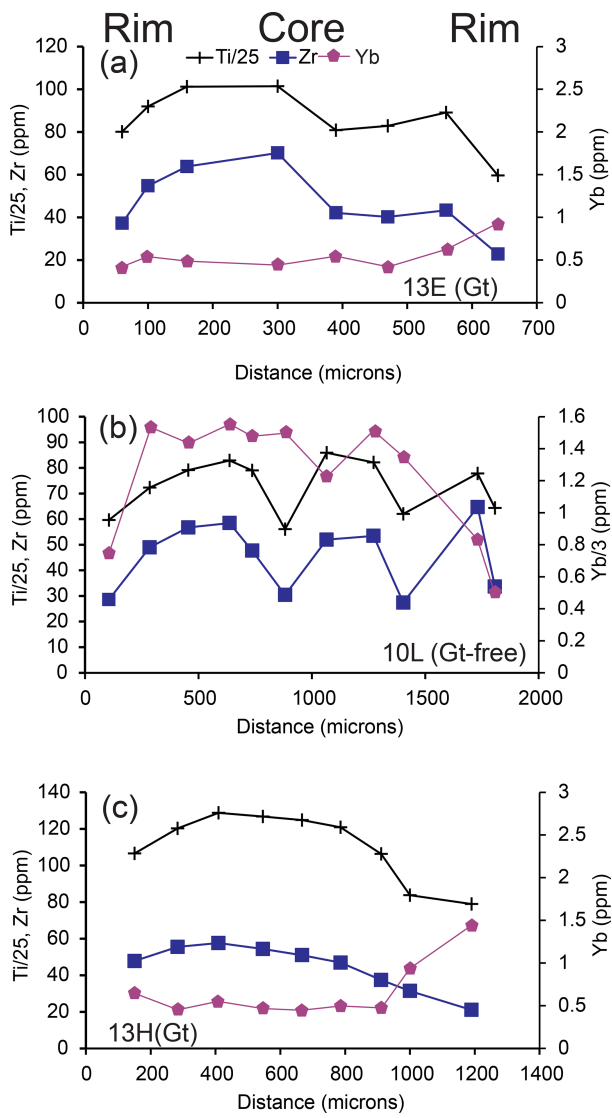

Figure 5. Core-to-rim trace element variation in clinopyroxene. (a) Type 1 clinopyroxene (sample 13E) from rim to rim; core is at $\sim 300 \mu \mathrm{m}$. Ti and $\mathrm{Zr}$ are depleted in the rims. $\mathrm{Yb}$ is enriched in the right rim, where the clinopyroxene is in contact with plagioclase and garnet-breakdown products. (b) Garnet-free type 2 clinopyroxene (sample 10L) from rim to rim; core is at $\sim 1000 \mu \mathrm{m}$. Ti and $\mathrm{Zr}$ are depleted in the rims. $\mathrm{Yb}$ is depleted in both rims. (c) Garnetbearing type 2 clinopyroxene (Sample 13H) from rim to rim; core is at $\sim 600 \mu \mathrm{m}$. $\mathrm{Ti}$ and $\mathrm{Zr}$ are depleted in the rims. $\mathrm{Yb}$ is enriched in the right rim, where the clinopyroxene is in contact with breakdown products of garnet. neous garnet (cf. Faryad et al., 2018). The variable chondritenormalised REE patterns and primitive mantle-normalised $\mathrm{Sr}$, $\mathrm{Hf}$ and $\mathrm{Ti}$ anomalies in clinopyroxene suggest that the samples were derived from at least two different parent magmas.

\subsection{Crystallisation conditions and the significance of the titanite ages}

Experimental studies of mafic magmas show that assemblages of clinopyroxene, garnet and plagioclase can be produced by high-pressure crystallisation (e.g. Green and Ringwood, 1967). Titanite in mafic rocks can form by a variety of subsolidus reactions (Xirouchakis et al., 2001a, b). In the samples described here, titanite coexists with plagioclase, quartz, clinopyroxene and ilmenite (and ulvöspinel in $13 \mathrm{H})$. The titanite likely formed by a reaction similar to (Xirouchakis et al., 2001a)

clinopyroxene + ilmenite $\leftrightarrow$ titanite + quartz + spinel

as part of subsolidus equilibration. This subsolidus event is likely simply the continuation of cooling after the formation of cumulates. Hirschmann et al. (1997) have shown that subsolidus reactions in the Skaergaard intrusion resulted in formation of titanite by reaction at $690-720^{\circ} \mathrm{C}, \sim 0.2 \mathrm{Myr}$ after initial intrusion.

In the present case, the reaction conditions needed for titanite formation by subsolidus reaction can be estimated using the Theriak-Domino thermodynamic calculation program (de Capitani and Brown, 1987; de Capitani and Petrakakis, 2010) and the composition of a xenolith, determined from the mode and mineral compositions. A pseudo-section produced using the thermodynamic database of Berman et al. (1985) indicates that titanite forms at $\sim 1 \mathrm{GPa}$ under the temperature conditions indicated from thermometry (Fig. 8) and that the main mineral assemblage matches that observed. Using this estimated pressure, the magma that formed the parent body of the xenoliths was intruded at a depth of $\sim 30 \mathrm{~km}$. At this depth, a $1 \mathrm{~km}$ thick sill emplaced at $1250^{\circ} \mathrm{C}$ with the lower contact at $30 \mathrm{~km}$ and a $25^{\circ} \mathrm{C} \mathrm{km}^{-1}$ 

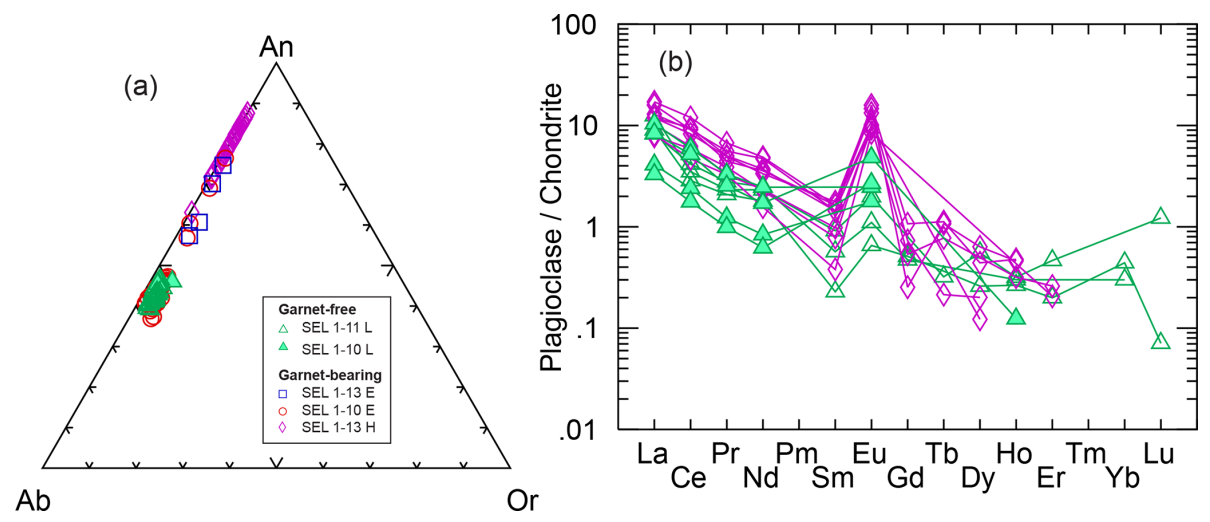

Figure 6. Major and trace element variation in plagioclase. (a) Plagioclase compositions showing that the samples $13 \mathrm{E}$ and $13 \mathrm{H}$ are significantly more calcic than the two garnet-free samples and sample 10E. (b) Chondrite-normalised REE plot (normalisation values of Sun and McDonough, 1989).

geothermal gradient, mantle density of $3300 \mathrm{~kg} \mathrm{~m}^{-3}$, crust density of $2900 \mathrm{~kg} \mathrm{~m}^{-3}$, thermal conductivity of 4.2 and $3.0 \mathrm{~W} \mathrm{~m}^{-1} \mathrm{~K}^{-1}$ for mantle and crust respectively, and a heat capacity of $1200 \mathrm{~J} \mathrm{~kg}^{-1} \mathrm{~K}^{-1}$ (Petford and Gallagher, 2001) would equilibrate with the geotherm after 1 to $1.2 \mathrm{Myr}$, based on the HEAT3D model of Wohletz et al. (1999). Thus, although the $\mathrm{U}-\mathrm{Pb}$ ages determined for the titanites do not correspond to the primary igneous event, they do closely correspond to the age of the intrusive event(s) that formed the granulites.

\subsection{Formation of symplectites}

Mineral breakdown reactions may be due to heating prior to xenolith entrainment or to post-entrainment reactions between the xenolith minerals and host (Shaw and Edgar, 1997; Canil and Fedortchouk, 1999; Shaw, 1999; Shaw and Klügel, 2002; Shaw et al., 2006; Shaw, 2009b). Orthopyroxeneplagioclase symplectites are common around garnets in granulite terranes (Harley, 1989) and are interpreted as being related to decompression during exhumation. However, a similar reaction should occur in the case of isobaric heating since in both cases the garnet stability curve is overstepped. In many granulite terranes and where garnet is preserved as megacrysts in kimberlite (Canil and Fedortchouk, 1999; O'Brien and Rötzler, 2003; Tam et al., 2012) it is partly preserved with coronas of variable width of intergrown orthopyroxene and plagioclase, indicating that the reaction period was short enough to leave behind relict garnet. In the samples described here, there is no garnet remaining in any of the samples.

Obata et al. (2014) produced a very similar symplectic orthopyroxene-plagioclase-spinel assemblage during experimental breakdown of garnet at $0.85 \mathrm{GPa}$ and $1100^{\circ} \mathrm{C}$. The minimum temperature for breakdown in the Rockeskyllerkopf samples is estimated as $925^{\circ} \mathrm{C}$ at $1.1 \mathrm{GPa}$ from the phase relations shown in Fig. 8. The rate of symplectite formation calculated by Dégi et al. (2010) suggests that garnets with a radius of $1 \mathrm{~mm}$ could be completely replaced in as little as 40000 years at high temperature $\left(\sim 1050^{\circ} \mathrm{C}\right)$ and as long as 3 million years near the garnet stability curve.

In sample $13 \mathrm{H}$, clinopyroxene shows a wide range in HREE. Low HREEs are expected for clinopyroxene crystallising in equilibrium with garnet, which would sequester more HREEs than clinopyroxene. High REE or unfractionated REE would result from crystallisation in the absence of garnet. The zonation in the outer part of the clinopyroxene crystals (Fig. 5) can be interpreted as being due to diffusive addition of HREE released by the garnet breakdown. The width of these zones is around $50 \mu \mathrm{m}$. Based on extrapolation of Van Orman et al. (2001) tracer diffusion data for $\mathrm{Yb}$ to $925^{\circ} \mathrm{C}$, which is the minimum temperature for garnet breakdown based on phase relations (Fig. 8), these would take $\sim 1.5 \mathrm{Myr}$ to form. With heating to $1050{ }^{\circ} \mathrm{C}$, the observed profiles could form in as little as 60000 years. The estimate of the duration of the breakdown event from the kinetics of symplectite formation and diffusion rates are in general agreement. It is not possible to determine the conditions or age of breakdown from the available data. A thermal disturbance large enough to drive breakdown would decay over time, and it is likely that garnet would reform from the symplectite assemblage. For this reason, it seems most likely that the disturbance is young, possibly associated with Tertiary or even Quaternary magmatism. There is evidence of magma accumulations in the lithospheric mantle on this timescale (Shaw et al., 2018). Hence, it is not unreasonable to suggest that magma flux and the increase in temperature that would be associated with it might lead to heating that would affect the granulitic base of the crust and cause garnet breakdown. 

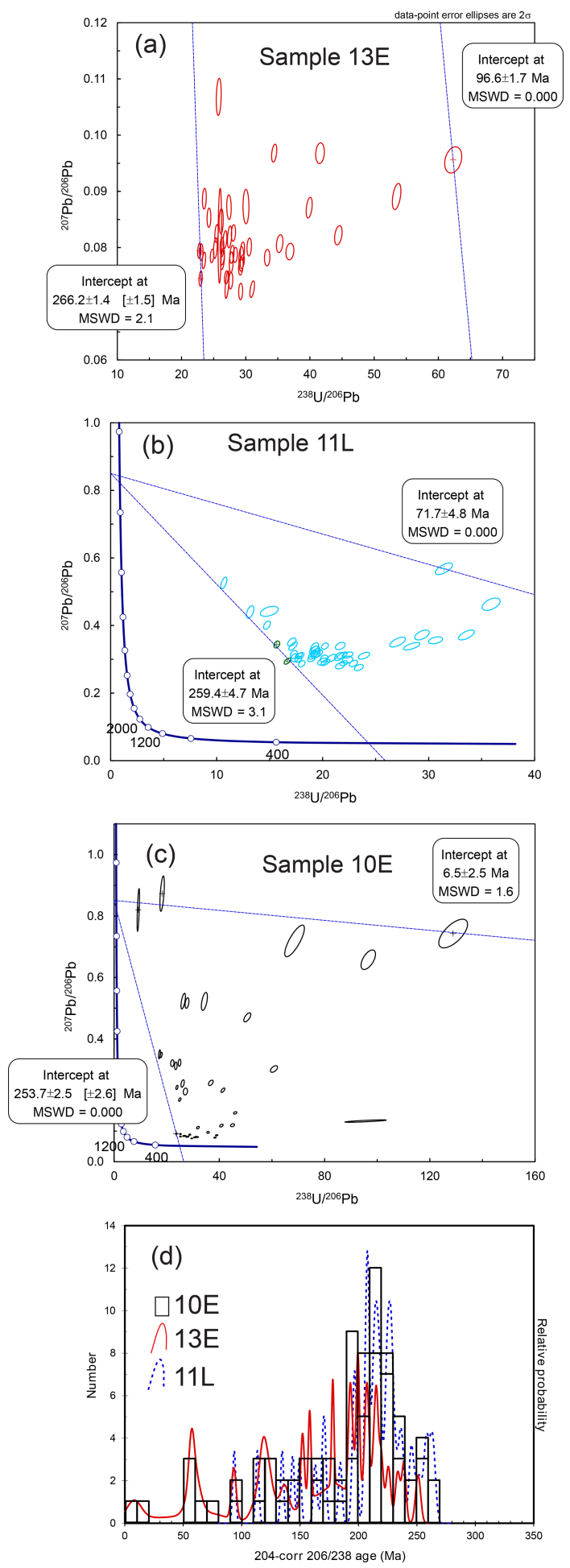

Figure 7. Titanite geochronology. (a-c) Tera-Wasserburg plots for samples $13 \mathrm{E}, 11 \mathrm{~L}$ and $10 \mathrm{E}$. Error ellipses are plotted at $2 \sigma$. The lines fit to the data give the interpreted crystallisation age (left most intercept), and the minimum disturbed age is given by the lower intercept. (d) Probability density plot for samples 13E, 11L and 10E showing the range of interpreted crystallisation ages and the timing of the interpreted reheating events.

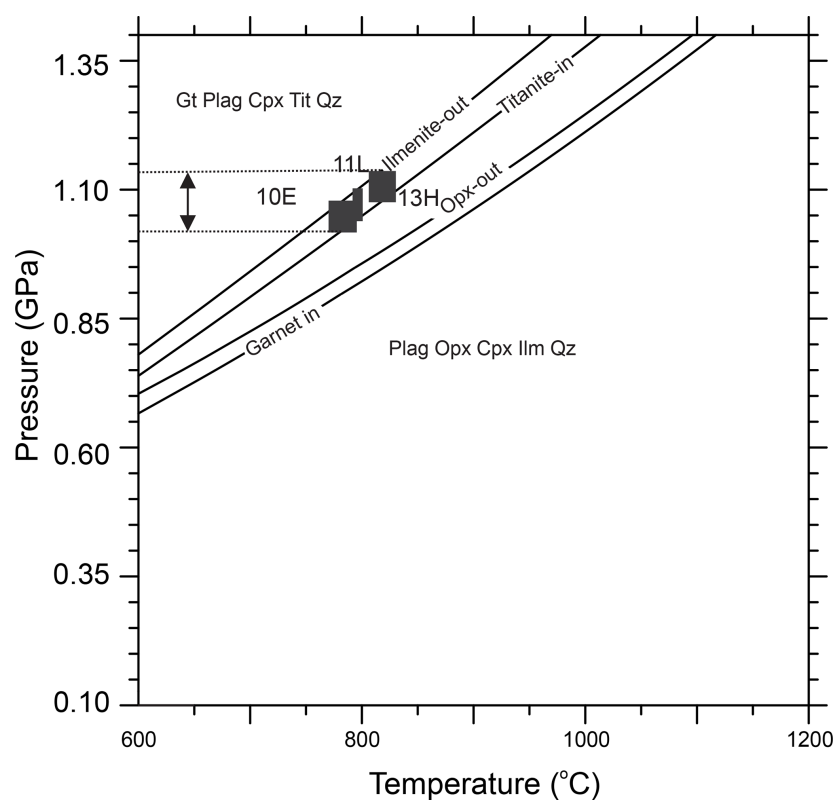

Figure 8. Pseudosection for sample 11L calculated with TheriakDomino (de Capitani and Brown 1987; de Capitani and Petrakakis, 2010) using the database of Berman et al. (1985). The grey boxes show the estimated temperature for samples $10 \mathrm{~L}, 10 \mathrm{E}$ and $13 \mathrm{H}$. Pressure is bracketed by the titanite in- and ilmenite out-curves since both phases are present. This indicates a pressure of 1 to $1.15 \mathrm{GPa}$ for the titanite-forming reaction. Gt: garnet. Plag: plagioclase. Opx: orthopyroxene. Cpx: clinopyroxene. Ilm: ilmenite. Qz: quartz. Tit: titanite. The bulk composition input into the file THERIN is Si (50.491), Ti (1.0306), Al (14.681), Fe (6.409), Mn (0.232), Mg (6.052), Ca (14.497), Na (6.114), K (0.217) and O (?). This composition also gives trace tephroite as a phase at all pressures - this has been omitted from the phase assemblage for simplicity.

\section{Geodynamic implications}

The only other samples of lower-crustal material from the Eifel region are the granulite xenoliths from Engeln in the East Eifel (Okrusch et al., 1979; Stosch et al., 1986, 1992; Schmincke, 2007). The Engeln samples comprise two suites - one with a depleted mantle model age of ca. 1.6 Gyr with metasomatism at $172 \pm 5 \mathrm{Myr}$ and a second suite with an igneous age of $412 \pm 81 \mathrm{Myr}$ and reheating events at 170 and $100 \mathrm{Myr}$.

The late Permian age and interpreted igneous protolith of the granulites from West Eifel suggest growth of the lower crust by addition of mafic magma following the collapse of the Permo-Carboniferous Hercynian Orogen. There is evidence of late Hercynian magmatism across much of northwest Europe from Scotland and the Massif Central (Upton et al., 2004; Berger et al., 2007) to the Southern Permian Basin (Benek et al., 1996; Timmerman et al., 2009) and the SaarNahe region of Germany (Schmidberger and Hegner, 1999). In the Eifel region, Meyer (1994) reports porphyry breccia 
and tuff in the Permian Wittlich Basin, which lies just south of the West Eifel Volcanic Field. Further west in the Massif Central (France), Féménias et al. (2003) and Berger et al. (2007) reported lower-crustal granulites of similar age $(257 \pm 6 \mathrm{Myr})$, which they interpret as fragments of a deep crustal layered intrusion.

The range of lower intercept ages for titanite indicates multiple post-crystallisation reheating events (Fig. 7). The oldest of these events was bracketed between 200-230 Ma and can be speculatively correlated with magmatism associated with the breakup of Pangea (Dèzes et al., 2004; Ziegler and Dèzes, 2005). Marzoli et al. (2014) and Pozsgai et al. (2017) reported Upper Triassic igneous rocks in NW France and in the Pannonian Basin, which they relate to the development of the Central Atlantic Magmatic Province. Large-scale transport of magma into and through the crust at this time could explain the first event of post-equilibration reheating.

Following the peak of reheating recorded at $\sim 220 \mathrm{Ma}$, there was almost continuous disturbance of the U-Pb systematics in titanite until $\sim 50 \mathrm{Ma}$. This is in accord with the conclusions of Ziegler and Dèzes (2005), who suggested that there was thermal re-equilibration of the lithosphericasthenospheric mantle associated with subsidence of sag basins throughout the Mesozoic. The youngest discordant, $\mathrm{Pb}$-corrected ages of the titanite range from $\sim 20$ to $6 \mathrm{Myr}$, which may correlate with formation of a thermal anomaly above what was to become the Eifel plume (Dèzes et al., 2004). The widespread Tertiary volcanic rocks in the neighbouring Hocheifel region range in age from 44 to $35 \mathrm{Myr}$ (Fekiacova et al., 2007), which could also explain some of the reheating.

Together the two suites of granulites from Eifel point to a long history of crustal growth beginning at $1.6 \mathrm{Ga}$ with clearly defined intrusive events at $\sim 400$ and $\sim 260$ Ma with numerous periods of metasomatism and reheating.

Data availability. All data are included in the Supplement.

Supplement. The supplement related to this article is available online at: https://doi.org/10.5194/ejm-33-233-2021-supplement.

Competing interests. The author declares that there is no conflict of interest.

Acknowledgements. Thanks to Calvin Nash and Stephen Delahunty for producing the thin sections used in this study. Thanks also to Douglas Hall, Stephen Cogswell and Brandon Boucher for their assistance with mineral analysis; Chris Zelt for discussions on the interpretation of the titanite geochronology data; and Johana Gomez for comments on an earlier draft of the manuscript. I am very grateful for the constructive reviews provided by Luca Ziberna and an anonymous referee and to Riccardo Tribuzio and Elisabetta Rampone for their editorial work. This project was funded through a Discovery Grant from the Natural Sciences and Engineering Research Council of Canada and the Boylen Fund administered by the University of New Brunswick.

Financial support. This research has been supported by the Natural Sciences and Engineering Research Council of Canada (Discovery Grant).

Review statement. This paper was edited by Riccardo Tribuzio and reviewed by Luca Ziberna and one anonymous referee.

\section{References}

Aleinikoff, J. N., Wintsch, R. P., Tollo, R. P., Unruh, D. M., Fanning, C. M., and Schmitz, M. D.: Ages and origins of rocks of the Killingworth dome, south-central Connecticut: Implications for the tectonic evolution of southern New England, Amer. J. Sci., 307, 63-118, 2007.

Benek, R., Kramer, W., McCann, T., Scheck, M., Negendank, J. F. W., Korich, D., Huebscher, H. D., and Bayer, U.: PermoCarboniferous magmatism of the Northeast German Basin, Tectonophysics, 266, 379-404, 1996

Berger, J., Féménias, O., Coussaert, N., Mercier, J.-C. C., and Demaiffe, D.: Cumulating processes at the crust-mantle transition zone inferred from Permian mafic-ultramafic xenoliths (Puy Beaunit, France), Contrib. Mineral. Petrol., 153, 557-575, 2007.

Berman, R. G., Brown, T. H., and Greenwood, H. J.: An internally consistent thermodynamic database for minerals in the system $\mathrm{Na}_{2} \mathrm{O}-\mathrm{K}_{2} \mathrm{O}-\mathrm{CaO}-\mathrm{MgO}-\mathrm{FeO}-\mathrm{Fe}_{2} \mathrm{O}_{3}-\mathrm{Al}_{2} \mathrm{O}_{3}-\mathrm{SiO}_{2}-\mathrm{TiO}_{2}-$ $\mathrm{H}_{2} \mathrm{O}-\mathrm{CO}_{2}$, Atomic Energy of Canada, Technical Report 377, Pinawa, Manitoba, 1985.

Büchel, G.: Vulkanologische Karte West- und Hocheifel, Landesvermessungsamt Rheinland-Pfalz, 1991.

Büchel, G. and Mertes, H.: Die Eruptionszentren des Westeifeler Vulkanfeldes, Z. Dtsch. Geol. Gesell., 133, 409-429, 1982.

Canil, D. and Fedortchouk, Y.: Garnet dissolution and the emplacement of kimberlites, Earth Planet. Sc. Lett., 167, 227-237, 1999.

Chew, D. M., Petrus, J. A., and Kamber, B. S.: U-Pb LA-ICPMS dating using accessory mineral standards with variable common Pb, Chem. Geol., 363, 185-199, 2014.

de Capitani, C. and Brown, T. H.: The computation of chemical equilibrium in complex systems containing non-ideal solutions, Geochim. Cosmochim. Ac., 51, 2639-2652, 1987.

de Capitani, C. and Petrakakis, K.: The computation of equilibrium assemblage diagrams with Theriak/Domino software, Amer. Miner., 95, 1006-1016, 2010.

Dégi, J., Abart, R., Török, K., Bali, E., Wirth, R., and Rhede, D.: Symplectite formation during decompression induced garnet breakdown in lower crustal mafic granulite xenoliths: mechanisms and rates, Contrib. Mineral. Petrol., 159, 293-314, 2010.

Dèzes, P., Schmid, S., and Ziegler, P.: Evolution of the European Cenozoic Rift System: interaction of the Alpine and Pyrenean orogens with their foreland lithosphere, Tectonophysics, 389, 133, 2004. 
Ernst, W. G. and Liou, J. G.: High- and ultrahigh-pressure metamorphism: Past results and future prospects, Amer. Miner., 93, 1771-1786, 2008.

Faak, K., Chakraborty, S., and Coogan, L. A.: Mg in plagioclase: Experimental calibration of a new geothermometer and diffusion coefficients, Geochim. Cosmochim. Ac., 123, 195-217, 2013.

Faryad, S. W., Jedlicka, R., Hauzenberger, C., and Racek, M.: High-pressure crystallization vs. recrystallization origin of garnet pyroxenite-eclogite within subduction related lithologies, Mineral. Petrol., 112, 603-616, 2018.

Fekiacova, Z., Mertz, D. F., and Renne, P. R.: Geodynamic Setting of the Tertiary Hocheifel Volcanism (Germany), Part I: ${ }^{40} \mathrm{Ar} /{ }^{39} \mathrm{Ar}$ geochronology, in: Mantle Plumes: A Multidisciplinary Approach, edited by: Ritter, J. R. R. and Christensen, U. R., Springer, Berlin, Heidelberg, 185-206, 2007.

Féménias, O., Coussaert, N., Bingen, B., Whitehouse, M., Mercier, J.-C. C., and Demaiffe, D.: A Permian underplating event in late- to post-orogenic tectonic setting. Evidence from the maficultramafic layered xenoliths from Beaunit (French Massif Central), Chem. Geol., 199, 293-315, 2003.

Frost, B. R., Chamberlain, K. R., and Schumacher, J. C.: Sphene (titanite): phase relations and role as a geochronometer, Chem. Geol., 172, 131-148, 2001.

Green, D. H. and Ringwood, A. E.: The Genesis of basaltic magmas, Contrib. Mineral. Petrol., 15, 103-190, 1967.

Hajdas, I., Zolitschka, B., Ivy-Ochs, S. D., Beer, J., Bonani, G., Leroy, S. A. G., Negendank, J. W., Ramrath, M., and Suter, M.: AMS radiocarbon dating of annually laminated sediments from lake Holzmaar, Germany, Quaternary Sci. Rev., 14, 137-143, 1995.

Harley, S. L.: The origins of granulites: a metamorphic perspective, Geol. Mag., 126, 215-247, 1989.

Hartnady, M. I. H., Kirkland, C. L., Clark, C., Spaggiari, C. V., Smithies, R. H., Evans, N. J., and McDonald, B. J.: Titanite dates crystallization: Slow $\mathrm{Pb}$ diffusion during super-solidus reequilibration, J. Metamorph. Geol., 37, 823-838, 2019.

Hayden, L. A., Watson, E. B., and Wark, D. A.: A thermobarometer for sphene (titanite), Contrib. Mineral. Petrol., 155, 529-540, 2008.

Hirschmann, M. M., Renne, P. R., and McBirney, A. R.: ${ }^{40} \mathrm{Ar} /{ }^{39} \mathrm{Ar}$ dating of the Skaergaard intrusion, Earth Planet. Sc. Lett., 146, 645-658, 1997.

Illies, J. H., Prodehl, C., Schmincke, H.-U., and Semmel, A.: The Quaternary uplift of the Rhenish shield in Germany, Tectonophysics, 61, 197-225, 1979.

Keyser, M., Ritter, J. R. R., and Jordan, M.: 3D shear-wave velocity structure of the Eifel plume, Germany, Earth Planet. Sc. Lett., 203, 59-82, 2002.

Kramers, J. D. and Tolstikhin, I. N.: Two terrestrial lead isotope paradoxes, forward transport modelling, core formation and the history of the continental crust, Chem. Geol., 139, 75-110, 1997.

Lloyd, F. E. and Bailey, D. K.: Light element metasomatism of the continental mantle: The evidence and the consequences, Phys. Chem. Earth, 9, 389-416, 1975.

Loock, G., Stosch, H.-G., and Seck, H. A.: Granulite facies lower crustal xenoliths from the Eifel, West Germany: petrological and geochemical aspects, Contrib. Mineral. Petrol., 105, 24-41, 1990.
Marzoli, A., Jourdan, F., Bussy, F., Chiaradia, M., and Costa, F.: Petrogenesis of tholeiitic basalts from the Central Atlantic magmatic province as revealed by mineral major and trace elements and $\mathrm{Sr}$ isotopes, Lithos, 188, 44-59, 2014.

Mengel, K., Sachs, P. M., Stosch, H. G., Wörner, G., and Loock, G.: Crustal xenoliths from Cenozoic volcanic field of West Germany: Implications for structure and composition of the continental crus, Tectonophysics, 195, 271-289, 1991.

Mertes, H.: Aufbau und Genese des Westeifeler Vulkanfeldes, Bochumer Geologische und Geotechnische Arbeiten, thesis, 9, 415 pp., 1983.

Mertes, H. and Schmincke, H.-U.: Age Distribution of Volcanoes in the West-Eifel, Neu. Jb. Geol. Paläont., Abh., 166, 260-293, 1983.

Mertes, H. and Schmincke, H.-U.: Mafic potassic lavas of the Quaternary West Eifel volcanic field, Contrib. Mineral. Petrol., 89, 330-345, 1985.

Mertz, D. F., Loehnertz, W., Nomade, S., Pereira, A., Prelevic, D., and Renne, P.: Temporal-spatial evolution of low-SiO 2 volcanism in the Pleistocene West Eifel volcanic field (West Germany) and relationship to upwelling asthenosphere, J. Geodyn., 88, 5979, 2015.

Meyer, W.: Geologie der Eifel, E. Schweizerbart'sche Verlagsbuchhandlung, Stuttgart, 1994.

Nowell, D., Jones, M., and Pyle, D.: Episodic Quaternary volcanism in France and Germany, J. Quat. Sci., 21, 645-675, 2006.

Obata, M., Ohi, S., and Miyake, A.: Experimental synthesis of isochemical kelyphite - a preliminary report, J. Mineral. Petrol. Sci., 109, 91-96, 2014.

O’Brien, P. J. and Rötzler, J.: High-pressure granulites: formation, recovery of peak conditions and implications for tectonics, J. Metamorph. Geol., 21, 3-20, 2003.

Okrusch, M., Schroder, B., and Schnutgen, A.: Granulite-facies metabasite ejecta in the Laacher See area, Eifel, West Germany, Lithos, 12, 251-270, 1979.

Paton, C., Hellstrom, J., Paul, B., Woodhead, J., and Hergt, J.: Iolite: Freeware for the visualisation and processing of mass spectrometric data, J. Anal. Atomic Spect., 26, 2508-2518, 2011.

Pearce, N., Perkins, W., Westgate, J., Gorton, M., Jackson, S., Neal, C., and Chenery, S.: A compilation of new and published major and trace element data for NIST SRM 610 and NIST SRM 612 glass reference materials, Geostand. News., 21, 115-144, 1997.

Petford, N. and Gallagher, K.: Partial melting of mafic (amphibolitic) lower crust by periodic influx of basaltic magma, Earth Planet. Sc. Lett., 193, 483-499, 2001.

Pozsgai, E., Józsa, S., Dunkl, I., Sebe, K., Thamó-Bozsó, E., Sajó, I., Dezső, J., and von Eynatten, H.: Provenance of the Upper Triassic siliciclastics of the Mecsek Mountains and Villány Hills (Pannonian Basin, Hungary): constraints to the Early Mesozoic paleogeography of the Tisza Megaunit, Int. J. Earth. Sci., 106, 2005-2024. 2017.

Prodehl, C.: Structure of the crust and upper mantle beneath the central european rift system, Tectonophysics, 80, 255-269, 1981

Prodehl, C., Mueller, S., Glahn, A., Gutscher, M., and Haak, V.: Lithospheric cross sections of the European Cenozoic rift system, Tectonophysics, 208, 113-138, 1992.

Ritter, J. R. R., Jordan, M., Christensen, U. R., and Achauer, U.: A mantle plume below the Eifel volcanic fields, Germany, Earth Planet. Sc. Lett., 186, 7-14, 2001. 
Rudnick, R. L. and Goldstein, S. L.: The Pb isotopic compositions of lower crustal xenoliths and the evolution of lower crustal $\mathrm{Pb}$, Earth Planet. Sc. Lett., 98, 192-207, 1990.

Schmidberger, S. S. and Hegner, E.: Geochemistry and isotope systematics of calc-alkaline volcanic rocks from the Saar-Nahe basin (SW Germany) \pm implications for Late-Variscan orogenic development, Contrib. Mineral. Petrol., 135, 373-385, 1999.

Schmincke, H. U.: The Quaternary Volcanic Fields of the East and West Eifel (Germany), in: Mantle Plumes: A Multidisciplinary Approach, edited by: Ritter, J. R. R. and Christensen, U. R., Springer, Berlin, Heidelberg, 241-322, 2007.

Schnepp, E. and Hradetzky, H.: Combined paleointensity and 40Ar/39Ar age spectrum data from volcanic rocks of the West Eifel field (Germany): Evidence for an early Brunhes geomagnetic excursion, J. Geophys. Res., 99, 9061-9076, 1994.

Seiberlich, C. K. A., Ritter, J. R. R., and Wawerzinek, B.: Topography of the lithosphere-asthenosphere boundary below the Upper Rhine Graben Rift and the volcanic Eifel region, Central Europe, Tectonophysics, 603, 222-236, 2013.

Shaw, C. S. J.: Dissolution of orthopyroxene in basanitic magma between 0.4 and $2 \mathrm{GPa}$ : further implications for the origin of Si-rich alkaline glass inclusions in mantle xenoliths, Contrib. Mineral. Petrol., 135, 114-132, 1999.

Shaw, C. S. J.: Caught in the act - The first few hours of xenolith assimilation preserved in lavas of the Rockeskyllerkopf volcano, West Eifel, Germany, Lithos, 112, 511-523, 2009a.

Shaw, C. S. J.: Textural development of amphibole during breakdown reactions in a synthetic peridotite, Lithos, 110, 215-228, 2009b.

Shaw, C. S. J. and Edgar, A. D.: Post-entrainment mineral-melt reactions in spinel peridotite xenoliths from Inver, Donegal, Ireland, Geol. Mag., 134, 771-779, 1997.

Shaw, C. S. J. and Eyzaguirre, J.: Origin of megacrysts in the alkaline lavas of the West Eifel volcanic field, Germany, Lithos, 50, 75-95, 2000.

Shaw, C. S. J. and Klügel, A.: The pressure and temperature conditions and timing of glass formation in mantle-derived xenoliths from Baarley, West Eifel, Germany: the case for amphibole breakdown, lava infiltration and mineral - melt reaction, Mineral. Petrol., 74, 163-187, 2002.

Shaw, C. S. J. and Woodland, A. B.: The role of magma mixing in the petrogenesis of mafic alkaline lavas, Rockeskyllerkopf Volcanic Complex, West Eifel, Germany, Bull. Volcanol., 74, 359376, 2012.

Shaw, C. S. J., Eyzaguirre, J., Fryer, B. J., and Gagnon, J.: Regional Variations in the Mineralogy of Metasomatic Assemblages in Mantle Xenoliths from the West Eifel Volcanic Field, Germany, J. Petrol., 46, 945-972, 2005.

Shaw, C. S. J., Heidelbach, F., and Dingwell, D. B.: The origin of reaction textures in mantle peridotite xenoliths from Sal Island, Cape Verde: the case for "metasomatism" by the host lava, Contrib. Mineral. Petrol., 151, 681-697, 2006.

Shaw, C. S. J., Woodland, A. B., Hopp, J., and Trenholm, N.: Structure and evolution of the Rockeskyllerkopf Volcanic Complex, West Eifel Volcanic Field, Germany, Bull. Volcanol., 72, 971990, 2010.

Shaw, C. S. J., Lebert, B. S., and Woodland, A. B.: Thermodynamic Modelling of Mantle-Melt Interaction Evidenced by Veined Wehrlite Xenoliths from the Rockeskyllerkopf Volcanic
Complex, West Eifel Volcanic Field, Germany, J. Petrol., 59, 5986, 2018.

Spandler, C., Hammerli, J., Sha, P., Hilbert-Wolf, H., Hu, Y., Roberts, E., and Schmitz, M.: MKED1: A new titanite standard for in situ analysis of Sm-Nd isotopes and $\mathrm{U}-\mathrm{Pb}$ geochronology, Chem. Geol., 425, 110-126, 2016.

Stosch, H.-G.: Constitution and evolution of subcontinental upper mantle and lower crust in areas of young volcanism: Differences and similarities between the Eifel (F.R. Germany) and Tariat Depression (central Mongolia) as evidenced by peridotite and granulite xenoliths, Fortsch. Mineral., 65, 49-86, 1987.

Stosch, H. G., Lugmair, G. W., and Seck, H. A.: Geochemistry of granulite-facies lower crustal xenoliths: implications for the geological history of the lower continental crust below the Eifel, West Germany, Geol. Soc. Lond. Spec. Pub., 24, 309-317, 1986.

Stosch, H.-G., Schmucker, A., and Reys, C.: The nature and geological history of the deep crust under the Eifel, Germany, Terra Nova, 4, 53-62, 1992.

Sun, C. and Liang, Y.: A REE-in-plagioclase-clinopyroxene thermometer for crustal rocks, Contrib. Mineral. Petrol., 172, 24, https://doi.org/10.1007/s00410-016-1326-9, 2017.

Sun, S.-S. and McDonough, W. F.: Chemical and isotopic systematics of oceanic basalts: implications for mantle composition and processes, Geol. Soc. Lond. Spec. Pub., 42, 313-345, 1989.

Tam, P. Y., Zhao, G., Sun, M., Li, S., Wu, M., and Yin, C.: Petrology and metamorphic $\mathrm{P}-\mathrm{T}$ path of high-pressure mafic granulites from the Jiaobei massif in the Jiao-Liao-Ji Belt, North China Craton, Lithos, 155, 94-109, 2012.

Timmerman, M. J., Heeremans, M., Kirstein, L. A., Larsen, B. T., Spencer-Dunworth, E.-A., and Sundvoll, B.: Linking changes in tectonic style with magmatism in northern Europe during the late Carboniferous to latest Permian, Tectonophysics, 473, 375-390, 2009.

Upton, B. G. J., Stephenson, D., Smedley, P. M., Wallis, S. M., and Fitton, J. G.: Carboniferous and Permian magmatism in Scotland, Geol. Soc. Lond. Spec. Pub., 223, 195-218, 2004.

Van Orman, J. A., Grove, T. L., and Shimizu, N.: Rare earth element diffusion in diopside; influence of temperature, pressure and ionic radius, and an elastic model for diffusion in silicates, Contrib. Mineral. Petrol., 141, 687-703, 2001.

Vernon, R. H.: A practical guide to rock microstructure, Cambridge University Press, Cambridge, 2004.

Witt-Eickschen, G., Kaminsky, W., Kramm, U., and Harte, B.: The nature of young vein metasomatism in the lithosphere of the West Eifel (Germany): Geochemical and Isotopic constraints from the composite mantle xenoiths from the Meerfelder Maar, J. Petrol., 39, 155-185, 1998.

Witt-Eickschen, G., Seck, H. A., Mezger, K., Eggins, S. M., and Altherr, R.: Lithospheric mantle evolution beneath the Eifel (Germany): Constraints from $\mathrm{Sr}-\mathrm{Nd}-\mathrm{Pb}$ isotopes and trace element abundances in spinel peridotite and pyroxenite xenoliths, J. Petrol., 44, 1077-1095, 2003.

Wohletz, K., Civetta, L., and Orsi, G.: Thermal evolution of the Phlegraean magmatic system, J. Volcanol. Geotherm. Res., 91, 391-414, 1999.

Wörner, G., Schmincke, H.-U., and Schreyer, W.: Crustal xenoliths from the Quaternary Wehr volcano (East Eifel), Neu. Jb. Mineral. Abh., 144, 29-55, 1982. 
Xirouchakis, D., Lindsley, D. H., and Andersen, D. J.: Assemblages with titanite $\left(\mathrm{CaTiOSiO}_{4}\right), \mathrm{Ca}-\mathrm{Mg}$-Fe olivine and pyroxenes, $\mathrm{Fe}$ Mg-Ti oxides, and quartz; Part 1, Theory, Amer. Miner., 86, $247-$ 253, 2001a.

Xirouchakis, D., Lindsley, D. H., and Frost, B. R.: Assemblages with titanite $\left(\mathrm{CaTiOSiO}_{4}\right), \mathrm{Ca}-\mathrm{Mg}-\mathrm{Fe}$ olivine and pyroxenes, $\mathrm{Fe}$ Mg-Ti oxides, and quartz; Part II, Application, Amer. Miner., 86, 254-264, 2001b.
Ziegler, P. A. and Dèzes, P.: Evolution of the lithosphere in the area of the Rhine Rift System, Int. J. Earth. Sci., 94, 594-614, 2005.

Zolitschka, B., Negendank, J., and Lottermoser, B.: Sedimentological proof and dating of the early Holocene volcanic eruption of Ulmener Maar (Vulkaneifel, Germany), Geol. Rund., 84, 213 219, 1995. 